\title{
In Search of the Culprit. Aspects of Medieval Authorship
} Introduction

Over fifty years after Roland Barthes' essay La mort de l'auteur ('The Death of the Author') and Michel Foucault's Qu'est-ce qu'un auteur ('What Is an Author?') were first published, the concept of authorship is still central to literary studies, with medieval literary studies being no exception. ${ }^{1}$ The last two decades have brought with them a huge number of publications about the concept of authorship in general, as well as more specifically about concepts of medieval authorship. Whilst Alastair Minnis based his great book about medieval theories of authorship on the scholastic perspectives on the subject that existed in the late Middle Ages themselves, thereby putting forward a predominantly emic analysis of the topic, other scholars - such as Rüdiger Schnell, Sonja Glauch, and Eva von Contzen, to name but a few - have taken more etic approaches, in that they have primarily sought to tease out medieval assumptions about authorship by interpreting case studies that do not so explicitly foreground such ideas. ${ }^{2}$

Despite their different approaches to the subject of authorship, all these scholars have demonstrated that the ideas of authorship, or of the special functions of authorship, that we bring to a text have a significant impact on our reading and interpretation of it. Indeed, the category of 'author' seems indispensable for the contextualisation of texts and the organisation of literature. ${ }^{3}$ In many cases, the search for an author results in a vicious circle: the search for an actual historical person to whom authorship can be attributed relies on the texts themselves, while the information we have about such persons comes from other texts that are themselves equally unclear in terms of their authorship. At best, this search may provide us with an authorial character or an imaginative authorial subject constructed from a few anecdotes derived from other narrative sources. Yet even if we cannot find the empirical producers of medieval texts, we can still search for theoretical entities or authorial agencies that are all involved in the texts as aesthetic artefacts.

1 Barthes 1968; Foucault 1969.

2 Minnis 2010; Schnell 1998; Glauch 2010; von Contzen 2018.

3 Spoerhase 2007, p. 7. 
The editors of this volume both come from the field of Old Norse-Icelandic studies but are very much engaged in interdisciplinary collaborations. Both of us have been influenced by New Philology, and thus by the ideas of variance, mouvance, and the materiality and mediality of medieval texts. Such concepts posit specifically medieval texts as malleable, changeable works, comprised of many differing versions and transmitted in various medial and material forms, rather than as having the more unified or singular form that modern texts are often conceptualised as having by their readers. Nonetheless, we are aware that this does not mean that such texts are able to change or diverge without limits; each version of such a text may be different, but it is still always a version of something, and is therefore meant to be recognised as a version. In this framework, 'variance' thus means variance within certain margins or parameters, albeit within considerably wider and more diffuse parameters than we would expect to exist for a modern text. ${ }^{4}$

Whilst the variance and mouvance of a huge part of medieval texts in the vernacular have been widely acknowledged in scholarship, this has had little to no effect on how most scholars approach the concept of authorship in these texts. It seems that either the focus is still on the search for the one and only authorial agency thought to be responsible for a text, as mentioned above, or that the question of authorship goes entirely unaddressed. In addition to the well-known names that have long been treated in our field as referring to 'genuine' authors of medieval texts, in recent years a whole series of 'new' authorial figures have been brought forward, especially when it comes to old Norse literature, as is discussed in this volume in the contribution of Sigurður Ingibergur Björnsson, Steingrímur Páll Kárason, and Jón Karl Helgason. Yet when it comes to these supposed 'new' authors, it seems that we still know little more than their names and their affiliation to the best-known Icelandic families.

In the course of the so-called material or new philological turn in medieval studies, however, it has been noted that the modern concept of 'the author' - meaning a subject who composed and wrote down a story at the same time - is hardly tangible in medieval literary texts. Indeed, the variance of medieval texts indicates the impossibility of tracing the author as the mythical source of the true and original text. ${ }^{5}$ In this regard, it is notable that Old Norse-Icelandic texts show more variance during their transmission than do Latin or Middle High German texts.

Almost all old Norse-Icelandic texts that have been preserved in multiple manuscripts exist in at least two versions, and even in the transmission of a single version there is (sometimes considerable) variance between the manuscripts. Whilst only a few unfragmented texts are preserved in medieval manuscripts, by far the greatest part of the surviving corpus exists only in post-medieval, early modern paper manuscripts. Thus, there is no single case in which we have what might be called an 'original' or 
even an 'autograph', in the sense of a manuscript in the author's own handwriting, of a medieval Icelandic text. Nonetheless, it was for a long time the aim of philologists and the editions they produced to present a text as close as possible to a lost original or, rather, to an original that never existed in the first place - that was labelled as the text's 'archetype'. Only in the late $20^{\text {th }}$ century have we become more aware that the transmission of these texts is best understood not as a strictly linear, chronological and hierarchical phenomenon - in which we would be able to approximate the 'original' text if only we could establish a rigorous enough chronology for its surviving versions - but rather as an ongoing process of adapting and reproducing texts that are by no means fixed, in which the dynamic interplay between textual reception and textual production is brought to the fore. Although they have already inspired a great deal of very fruitful scholarly work, the theoretical and methodological approaches introduced by the new philological turn are not yet widespread in Old Norse-Icelandic studies, at least in our view. Since the idea of an unfixed text is hard to bear if one wants to study the sociohistorical conditions of literature at a certain time or to contextualise certain topics related to a text, it is often easier and more comfortable to neglect the debate over transmission and instead to return to viewing 'the text', or even 'the work', as the product of one (probably male) educated being at a specific time in a specific surrounding. Thus, Old Norse texts are treated primarily as products of a time that, in most cases, is determined by (sometimes rather obscure) intra-textual features. This results, for example, in the classification of early, classical and post-classical Icelandic sagas, even though no scholars appear able to give any clear criteria as to why a given saga should be thought of as belonging to one of these rather arbitrary classes of text.

If we take seriously the variance and mouvance of medieval texts, we must also consider that within medieval literature the boundaries of work and text are fluid; each work can exist in different versions at the same time, and whilst we might consider some versions as new works in their own right, this may not have been the case for a contemporary audience. ${ }^{6} \mathrm{~A}$ work is constituted by different texts related by resemblance, i.e. relational aspects with different parameters depending on genre or text-type. ${ }^{7}$ Yet it is important to note that these similarities and relationships are not necessarily captured accurately by a stemma leading back to a supposed archetype, of the kind constructed by many modern philologists. ${ }^{8}$

of course, it is important to keep in mind that relationships between versions of a text - indeed, thinking of them as 'versions' at all - can only be possible if at least

6 Müller 1999, p. 165.

7 Müller compares this relationship to resemblance within a family; see Müller 1999, p. 163. A similar idea is used in genre theory; see Bampi 2020, p. 22.

8 Müller 1991, p. 163. In this respect Müller differs from Wendt 2006, who considers the relationship between text and work to always be a stemmatic one. 
some parts of a text are relatively stable. Variance must always be seen in relation to invariant parts of the text. This means both that there are different degrees of variance and that variance encompasses different phenomena. ${ }^{9}$ Some variants might be errors or mistakes, although we should make such claims only in restricted cases and should be wary of viewing them as indications of deterioration: in some cases, errors can result in a productive change to a text. Some variants may be due to spontaneous variation during oral performance. Most interesting for editors and interpreters, not to say most challenging, are those variants that appear to be based on decisions concerning the content, structure, or theming of a text, as is often the case with, for example, additions or omissions, comments, changes to the order of episodes, different emphases in certain areas, and so on.

Which variants and which version of a work will last the longest depends on various factors, including the differing aesthetic preferences of editors, compilers, and scribes. As textual anecdotes about the quality of a given story prove, aesthetic criteria were important to medieval audiences. The Old Norse-Icelandic Morkinskinna, a collection of Kings' sagas from the $13^{\text {th }}$ century but preserved in manuscripts from the $14^{\text {th }}$ century, contains an anecdote about an Icelander coming to the court of the Norwegian King Haraldr Sigurðarson. The king asks the Icelander to tell a story in different parts, one part of it every evening, so that it would last for the eleven days of Christmas. The king also wants those present to listen carefully: 'Sumum pykkir hann vel segja, en sumir vinnask minna at' ('Some thought he was telling well, others praised him less'). ${ }^{10}$ When the Icelander finishes his story, the king himself gives the final judgement: 'Mér bykkir allvel ok hvergi verr en efni eru til, eða hverr kenndi pér soguna?' ('I think it is very good and in no way worse than the matter allows for; who taught you the story?') ${ }^{11}$ The king judges not only the Icelander's performance of the story, but also its quality; clearly, to tell a story means, at least to some extent, to tell of a specific matter in one's own way. The storyteller does not only retell what he has learned, he also creates the story by retelling it.

The importance of retelling, rewriting, and the proliferation of medieval literature which are also at the core of a number of projects within the Collaborative Research Centre 1391 Different Aesthetics - has been observed before, ${ }^{12}$ but this observation has thus far had little impact on our reflections on the concept of authorship. ${ }^{13}$ When it comes to medieval literature, we quite often see a naïve usage of the term 'author', where the term is in many cases used, without any further reflection, in our modern emphatic sense, namely of a distinct individual behind a text. This sense, however, was

9 Müller 1999, p. 164.

10 Morkinskinna I, p. 236.

11 Morkinskinna I, p. 236.

12 On the importance of rewriting, see Worstbrock 1999.

13 See Nichols 2007. 
influenced by the development of new models of authorship in the $18^{\text {th }}$ and $19^{\text {th }}$ centuries when authors began to write for a living outside of courts, monasteries, or other patronage networks, and therefore needed to assert their individual rights to their works, a conceptual framework that cannot be accurately mapped on to the modes of textual production that characterised the medieval period.

The discussion about the 'death of the author' has thus had the consequence that we are now more aware of the complex nature of authorship. Or, as we might say: the dead author has returned as the idea of author-functions. ${ }^{14}$ Whenever we speak about literature, we will be confronted with one or more of these functions. ${ }^{15}$

A large part of medieval literature in general, and the best part of medieval old Norse-Icelandic literature in particular, is anonymous, but this does not mean that there was no concept of authorship at all in medieval Iceland and Scandinavia. Skaldic poetry, be it within the prosimetrum of Icelandic sagas or in treatises about poetry, is usually authored in texts, in the sense that it is often attributed to a specific named author. For skaldic poetry, it thus seems to have been important to associate poems and stanzas with a name to indicate that the stanzas 'belonged' to someone, regardless of whether such an association were historically accurate. For narrative texts or for epic verse, such as is more typically found in eddic poetry, this kind of attribution seems not to have been important. We cannot conclude from this of course, that a concept of authorship did not exist within this milieu, but we can certainly see that whatever concept of authorship did exist was different from our own modern conception.

As in the prosimetrical sagas, which present the anonymous narratorial voice of the prose alongside the voices of multiple authors of skaldic verse, the medieval author in general existed in the plural. Yet collaborative work undertaken at the same time on one text seems to have been the exception, with authorship usually reaching over several generations as texts continued to be altered, adapted, continued, and shortened - in other words, retold and rewritten. ${ }^{16}$ In this process, we can clearly see that the concept of authorship in the Middle Ages was not the same as the emphatic present-day notion; rather, the role played by an 'author' was far less definite and had a comparatively marginal position in the text.

The variance of medieval texts also indicates that the different functions that we associate with a single authorial figure are more widely distributed across various scribes, compilers, and editors in medieval literature. ${ }^{17}$ Nevertheless, within old

14 Foucault (1969) had already suggested in the 1960s that the author is a function of discourse. On Foucault's answer to Barthes, see Stougaard-Nielsen 2019, p. 279.

15 See Spoerhase 2007, pp. 12-18.

16 Müller 1999, p. 158. On retelling and rewriting in medieval literature, see Worstbrock 1999.

17 On distributed authorship see Ranković 2007; Ranković / Ranković 2012 and her contribution in this volume. 
Norse-Icelandic literary studies there seems to be a renewed motivation to identify an actual person behind the anonymous authorship of a given saga, which indicates a continued interest in the biographical function of the author for hermeneutical reasons. In other words, knowing the author of a text is in such studies posited as necessary for its proper contextualisation - always presupposing, of course, that it is a single author who is responsible for that text.

Even though in most cases there is no remotely reliable evidence for attributing the authorship of a medieval Old Norse-Icelandic text to a specific named figure, and despite the recognition of variance and mouvance as basic principles of medieval literature, the notion of the author as a specific person responsible for a text is still very much alive. The anonymity of Icelandic literature has predominantly been thought of as a defect of the texts that should be mended. Without specific authors, it seems difficult to accept an authority, invariably conceived as a historical person, speaking through a text, as well as to relate that text to a specific historical context; in short, an anonymous text lacks what we perceive as important authorial functions and does not correspond to our presupposition of a literary work of art. But since the anonymity of most Old Norse-Icelandic texts, as well as many other medieval European texts, does not seem to result from a loss occurring during the transmission process but appears to be a generic feature, it is more productive for us not to seek to mend supposed defects that may be nothing of the sort, but rather to attempt to understand the concept of anonymous authorship as a symptom of the pluralistic and undetermined forms of medieval authorship. We should accept that for a long time those involved in textual production did not feel the need to see their names attached to their products and thus to lay claim to the ownership of the work or to an authority built on the idea of an author as a literary creator.

The contributors to this volume address the question of medieval and early modern authorship from different theoretical and methodological angles, as well as in various philological fields of research. We all concentrate on aspects of authorship in textgenesis, transmission, and the hermeneutics of a text, and deal in one way or another with questions of authority - the 'culprit' for which we are searching then being the agency or agencies responsible for the text, in the sense of the authority or authorities that functioned to approve a text and thus its meaning.

Jürg Glauser shows how the 'Icelandic school', which was heavily influenced by the concept of the modern author, attempted to eliminate traces of a pre-modern concept of authorship in the sagas in its editions and interpretations, thus influencing scholarship in the field of Scandinavian studies to this day.

In his case study of the highly canonised author-figure Ari Porgilsson, Lukas Rösli explores the question of how authorship was discursively and intertextually produced in Old Norse-Icelandic literary history. 
In Stefanie Gropper's chapter, Sneglu-Halla páttr serves as a representative product of the pluralistic authorship reflected in the anonymous transmission of medieval Icelandic texts.

In their collaborative chapter, Sigurður Ingibergur Björnsson, Steingrímur Páll Kárason, and Jón Karl Helgason consider recent attempts to apply variations of the Burrows' Delta method to Old Norse-Icelandic sagas, and discuss the broader inferences of these findings regarding authorship and attribution to specific individuals.

Judy Quinn's contribution focuses on the ways in which anonymity participates in the textual construction of authority among the competing voices of prosimetrum.

Lena Rohrbach discusses in her chapter underlying concepts of authorship in studies of medieval compilations of the history of the Norwegian kings and unveils an intricate connection between notions of author and work in the wake of humanistic traditions that influence preconceptions of the relationship between manuscripts and works up to the present day.

Drawing on current studies into memory, agency, and artificial intelligence, Slavica Ranković revisits the concept of the 'distributed author' using Fóstbroðra saga as a case study.

Gudrun Bamberger's chapter on $16^{\text {th }}$-century vernacular literature demonstrates how authorship in the early modern period was to some extent still characterised by the presence of degrees of authorship and how it made use of various concepts of anonymity. She shows, however, that the Historia von D. Johann Fausten (1587) does attempt to frame itself as having its origins in a single author, namely the protagonist himself.

Matthias Bauer's and Angelika Zirker's collaborative chapter explores the presence of John Gower and Geoffrey Chaucer as medieval co-authors in Shakespeare's early modern plays.

In her study of the medieval Ármanns rimur and their early modern reworkings, Madita Knöpfle traces the rise of the author Eiríkur Laxdal in early modern Iceland against the background of contemporary discussions of the textual nature of prose and poetic literature and authorship.

Last but not least, Margrét Eggertsdóttir sheds light on ideas of medieval authors in early modern Iceland, when Icelandic scholars apparently found it necessary for the reputation of Icelandic literary history to identify 'real authors' comparable to the classical scriptores.

Despite the different angles and approaches that they take, all the contributions to this volume demonstrate how far-reaching the presuppositions of modern emphatic authorship have been in scholarship. Likewise, they all suggest that if we are to understand the concept of medieval authorship more accurately, we must move beyond such assumptions to accept the specifics of our texts, rather than attempting to efface or to distort those characteristics so that these texts fit our modern preconceptions of authorship. 


\section{Bibliography}

Bampi 2020 = Bampi, Massimiliano: Genre, in: Massimiliano Bampi / Carolyne Larrington / Sif Rikhardsdottir (eds.): A Critical Companion to Old Norse Literary Genre, Cambridge 2020, pp. 15-30.

Barthes 1968 = Barthes, Roland: La mort de l'auteur, in: Manteia (1968), pp. 12-17 [english translation: Barthes, Roland: The Death of the Author, in: Aspen Magazine 5/6 (1967), unpaginated].

von Contzen 2018 = Contzen, Eva von: Narrative and Experience in Medieval Literature. Author, Narrator, and Character Revisited, in: Eva von Contzen / Florian Kragl (eds.): Narratologie und mittelalterliches Erzählen. Autor, Erzähler, Perspektive, Zeit und Raum, Berlin 2018, pp. 61-79.

Foucault 1969 = Foucault, Michel: Qu'est-ce qu'un auteur, in: Bulletin de la Societé Française de Philosophie (Juli-September 1969), pp. 73-104.

Glauch 2010 = Glauch, Sonja: Ich-Erzähler ohne Stimme. Zur Andersartigkeit mittelalterlichen Erzählens zwischen Narratologie und Mediengeschichte, in: Harald Haferland / Mathias Meyer (eds.): Historische Narratologie - Mediävistische Perspektiven, Berlin 2010, pp. 149-185.

Minnis $2010=$ Minnis, Alastair J.: Medieval Theory of Authorship. Scholastic Literary Attitudes in the Later Middle Ages, $2^{\text {nd }}$ ed. Philadelphia 2010.

Morkinskinna, ed. by Ármann Jakobsson and pórður Ingi Guðjónsson, 2 vols., Reykjavík 2011.

Müller 1999 = Müller, Jan-Dirk: Aufführung - Autor - Werk. Zu einigen blinden Stellen gegenwärtiger Diskurse, in: Nigel F. Palmer / Hans-Jochen Schiewer (eds.): Mittelalterliche Literatur und Kunst im Spannungsfeld von Hof und Kloster. Ergebnisse der Berliner Tagung, 9.-11. Oktober 1997, Tübingen 1999, pp. 149-166 [reprinted in: Jan-Dirk Müller (ed.): Mediävistische Kulturwissenschaft. Ausgewählte Studien, Berlin / New York 2010, pp. 11-25].

Nichols 2007 = Nichols, Stephen G.: The Medieval "Author": An Idea Whose Time Hadn't Come?, in: Virginie Greene (ed.): The Medieval Author in French Literature, Palgrave 2007, pp. 77-101.

Ranković / Ranković 2012 = Ranković, Slavica / Ranković, Miloš: The Talent of the Distributed Author, in: Slavica Ranković / Ingvil Brügger Budal / Aidan Conti / Leidulv Melve / Else Mundal (eds.): Modes of Authorship in the Middle Ages, Toronto 2012, pp. 52-75.

Ranković 2007 = Ranković, Slavica: Who is Speaking in Traditional Texts? On the Distributed Author of the Sagas of Icelanders and Serbian Epic Poetry, in: New Literary History 38 (2007), pp. 293-307.

Schnell 1998 = Schnell, Rüdiger: 'Autor' und 'Werk' im deutschen Mittelalter. Forschungskritik und Forschungsperspektiven, in: Joachim Heinzle / L. Peter Johnson / Gisela Vollmann-Profe (eds.): Neue Wege der Mittelalter-Philologie. Landshuter Kolloquium 1996, Berlin 1998 (WolframStudien 15), pp. 12-73.

Spoerhase 2007 = Spoerhase, Carlos: Autorschaft und Interpretation. Methodische Grundlagen einer philologischen Hermeneutik, Berlin / New York 2007.

Stougaard-Nielsen 2019 = Stougaard-Nielsen, Jakob: The Author in Literary Theory and Theories of Literature, in: Ingo Berensmeyer / Gert Buelens / Marysa Demoor (eds.): The Cambridge Handbook of Literary Authorship, Cambridge / New York / Melbourne / New Delhi / Singapore 2019, pp. 270-287.

Wendt 2006 = Wendt, Bo-A.: En text är en text är en text? Om en terminologisk tredelning av textbegrepet, in: Arkiv för nordisk filologi 121 (2006), pp. 253-274.

Worstbrock 1999 = Worstbrock, Franz Josef: Wiedererzählen und Übersetzen, in: Walter Haug (ed.): Mittelalter und frühe Neuzeit. Übergänge, Umbrüche und Neuansätze, Tübingen 1999, pp. 128-142. 